CASE STUDY

\title{
Becoming a Public Square Detroit Institute of Arts
}

September 20, 2018

Liam Sweeney

Katherine Daniel

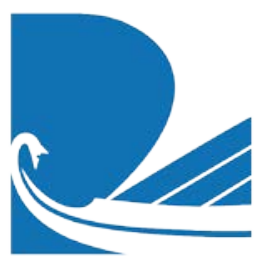

ITHAKA S+R 
THE

ANDREW W.

MELLON

romberion

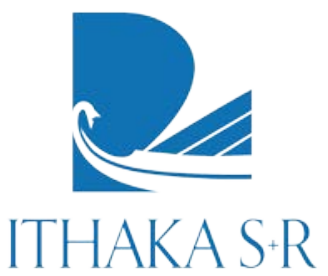

The Andrew W. Mellon Foundation endeavors to strengthen, promote, and, where necessary, defend the contributions of the humanities and the arts to human flourishing and to the wellbeing of diverse and democratic societies.

Ithaka $\mathrm{S}+\mathrm{R}$ provides research and strategic guidance to help the academic and cultural communities serve the public good and navigate economic, demographic, and technological change. Ithaka $\mathrm{S}+\mathrm{R}$ is part of ITHAKA, a notfor-profit organization that works to advance and preserve knowledge and to improve teaching and learning through the use of digital technologies. Artstor, JSTOR, and Portico are also part of ITHAKA.
Copyright 2018 The Andrew W. Mellon Foundation.. This work is licensed under a Creative Commons AttributionNonCommercial 4.0 International License. To view a copy of the license, please see http://creative-

commons.org/licenses/by-nc/4.0/.

The Mellon Foundation encourages distribution of the report. For questions, please write to Iw@mellon.org. 


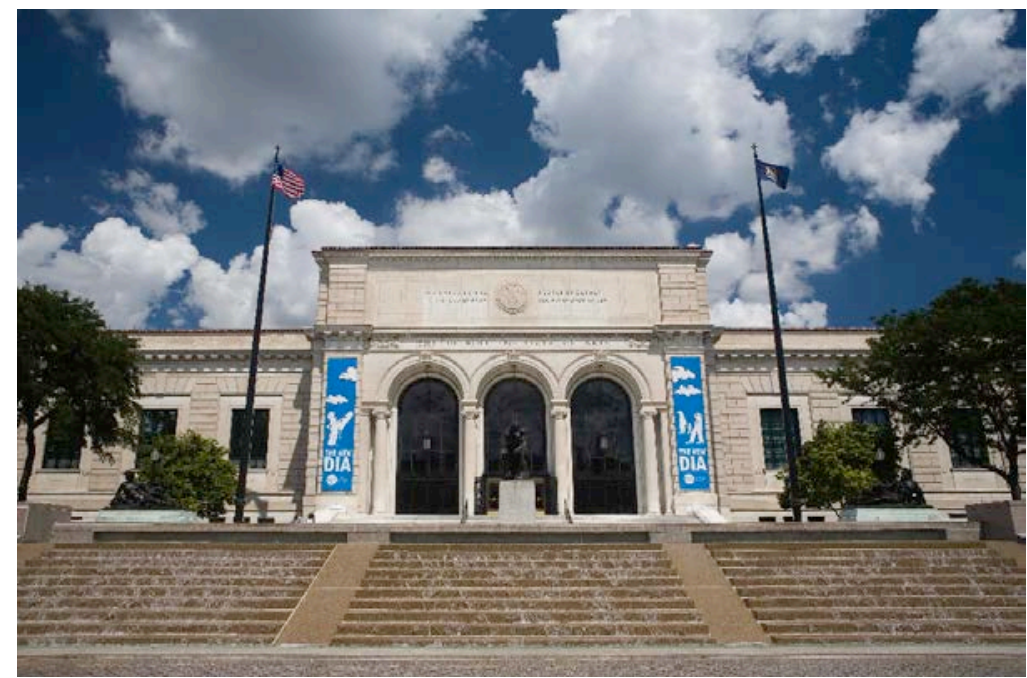

Detroit Institute of Arts Facade, Courtesy of the Detroit Institute of Arts

Located in midtown Detroit's cultural center, the Detroit Institute of Arts (DIA) is one of the largest encyclopedic museums in the country, housing nearly 66,000 works of art. From the outside, described by many of its staff as looking like a castle on a hill, one would not guess at the museum's turbulent history, stemming from a complex relationship with the city of Detroit. Today, DIA finds itself uniquely placed among American museums as having one of the highest rates of racial and ethnic diversity among its employees.

Following a leadership transition in 2015, the museum is in the process of implementing a broad set of strategies to engage the residents of Detroit more deeply. If the museum has had a tense relationship with the municipal government in recent years, it has also struggled to build trust with the people of Detroit. While the city is 82 percent African American, only 11 percent of DIA's visitors are. But as the museum has recently established a modest degree of financial stability, it has turned its attention toward the historically underserved communities that immediately surround it.

\section{Key Findings}

During the three-day site visit to DIA we interviewed 20 individuals, including staff and external partners. We observed an interdepartmental meeting and attended public events. Through this research, we found that DIA has developed three key strategies to create a more diverse, equitable, and inclusive environment:

1. Paid Internships: DIA sees unpaid internships as a significant barrier to entry for underrepresented groups, and has worked toward a paid internship model. 
2. Hosting: A focus on visitors and an emergent culture of hospitality has allowed the museum to be much more welcoming to historically excluded communities.

3. Evaluation: A commitment to evaluation has allowed the museum to collect evidence as it works to deepen engagement with visitors.

\section{Challenges and Tradeoffs}

1. Diversity across staff roles: While the museum has a high degree of representational diversity relative to the broader field, most people of color are employed in facilities and security positions or in the museum store. Recent strides in diversifying curatorial staff show that the museum is beginning to address the inequities underlying the high level of representational diversity.

2. Reaching communities: As the museum begins to focus on visitors, it has realized the importance of establishing a presence in historically excluded communities. But these efforts have been met with some skepticism; it takes time to establish trust.

\section{History and Context}

Founded as the Detroit Museum of Art in 1885, the museum came by its current name after its rapidly expanding collection necessitated a move to its present location on Woodward Avenue in 1927. Prior to that, in 1919, the museum was incorporated into the city as a municipal department, enabling it to purchase some of its most valuable works of art using city funds. However, it also ceased to be an independent entity in a move that would jeopardize the museum's existence nearly a hundred years later.

By all accounts, Detroit was a booming commercial and industrial hub prior to World War II and home to a critical American industry-automobile manufacturing. ${ }^{1}$ During the first three decades of the $20^{\text {th }}$ century, Detroit's population grew fivefold from 300,000 to 1.5 million as Henry Ford attracted domestic and international workers to the city with the promise of high wages. ${ }^{2}$ Along with the influx of white American and European workers, people of color also moved into the city, and by the 1920 s their numbers had grown to one tenth of the city's total population. A surge in defensejobs

\footnotetext{
1 Thomas J. Sugrue, "The Gilder Lehrman Institute of American History," Motor City: The Story of Detroit | Gilder Lehrman Institute of American History, January 01, 1970, accessed February 28, 2018, https://www.gilderlehrman.org/history-now/motor-city-storydetroit.

2 Alex L. Swan, "The Harlem and Detroit Riots of 1943: A Comparative Analysis," Berkeley Journal of Sociology, 16 (1971): $75-93$. http://www.jstor.org/stable/40999915.
} 
from 1940-43 brought another half a million people to Detroit. Segregationist practices in housing and labor exacerbated racial tensions and eventually began to disrupt Detroit's factories as workers took part in union strikes and strikes pertaining to racial issues. The automobile industry began to decentralize from Detroit in the 1950s, and the city's population of 1.85 million began to decline as workers followed manufacturing jobs to suburbs and other states. Automation had also started to replace many of thejobs that had traditionally been performed by assembly-line workers, so that by the start of the 2010s, one in five Detroit adults did not have work in the formal economy. ${ }^{3}$

Racial tensions continued to grow nationally until, on J uly 23, 1967, they erupted once again in one of the worst instances of civil unrest in U.S. history as the African American community rose up against a notoriously brutal police force. Forty-three people were killed and the city sustained $\$ 36$ billion in damages. ${ }^{4}$ Residents fled the city for the suburbs in a mass exodus. Those who remained were often unable to move for financial reasons, or would not have been welcome in suburbs that had segregated by race and ethnicity. Native Detroit author Ze'ev Chafets described a point system whereby "prospective buyers were rated by skin color, accent, religion and other criteria, including a 'typically American way of life.' Under the system, blacks, Mexicans and Orientals [sic] were automatically given a failing grade, as were virtually all $J$ ews and southern Europeans." 5 The dramatic decrease in population left the city with a vastly diminished tax base. Mismanagement of the city's finances across multiple administrations eventually led the city to file for bankruptcy in $2013 .{ }^{6}$

As a result of its ties to the city, DIA has faced similar challenges. The city of Detroit withdrew its funding for acquisitions in 1955, and gradual reductions in taxpayer support starting in 1990 made the museum reliant on fundraising for the majority of its operating budget by $2006 .{ }^{7}$ In 2012 , the museum requested and won a ten-year millage

\footnotetext{
${ }^{3}$ Amy Padnani, "Anatomy of Detroit's Decline," The New York Times, December 8, 2013, accessed July 26, 2017, http://www.nytimes.com/interactive/2013/08/17/us/detroit-decline.

4 Thomas J. Sugrue, "Conclusion: Crisis: Detroit and the Fate of Postindustrial America," in The Origins of the Urban Crisis: Race and Inequality in Postwar Detroit, 259-271, Princeton University Press, 2005, http://www.jstor.org/stable/j.ctt7rhfq.18.

${ }^{5}$ Ze'ev Chafets, "The Tragedy of Detroit," The New York Times, July 29, 1990, accessed July 5, 2017, http://www.nytimes.com/1990/07/29/magazine/the-tragedy-of-detroit.html?pagewanted=all.

${ }^{6}$ Nathan Bomey and John Gallagher, "How Detroit Went Broke: The Answers May Surprise You—and Don't Blame Coleman Young," September 15, 2013, Detroit Free Press, accessed June 30, 2017, https://www.freep.com/story/news/local/michigan/detroit/2013/09/15/how-detroit-went-broke-the-answers-may-surprise-youand/77152028/.

7 The 2006 operating budget was $\$ 31$ million.
} 
from the surrounding tri-county area, the success of which former director Graham Beal largely credits to a reinstallation undertaken from 1999-2007 to make the museum more visitor-oriented and engaging. ${ }^{8}$ After Detroit declared bankruptcy, the museum's collection was seen by some as an asset that could be liquidated to cover the city's financial deficits. As the specter of deaccessioning to finance public debt loomed in 2013 and 2014, judges, city officials, the governor and state legislators, and leaders of major foundations came together to seek an alternative solution, which became known as the "grand bargain." 9 To save the collection, over $\$ 800$ million was raised by foundations, private donors, and the state of Michigan. This unprecedented collaboration between major foundations, the city of Detroit, and the state allowed the city to preserve public workers' pensions and protected the collection for the public, in perpetuity, in an independent charitable trust. ${ }^{10}$ It also required the museum to develop five programs intended to serve the state of Michigan. These include biennial traveling exhibitions, an annual professional development program with the Michigan Museum Association, an expansion of the museum's outreach program Inside| Out, discounted conservation services for Michigan museums, and development of a new education program. It also was required to raise $\$ 100$ million for the city of Detroit. Thanks to the grand bargain and the millage to support the museum's operating costs, DIA is now more financially secure than it has been in many years. ${ }^{11}$

But the city of Detroit faces an uneven recovery. While downtown and midtown, comprising four percent of the city's population, have experienced growth, the narrative of recovery conceals steep inequities in income and access to facilities and services. ${ }^{12}$ J uanita Moore, director of the Charles H. Wright Museum of African American History located across the street from DIA, describes Detroit's fiscal and racial challenges as a model through which America can learn: "Detroit has all the problems of urban America. People think that this is the only place with these challenges but I think that these problems are so essentially American that if you can solve it in Detroit, you can solve it

\footnotetext{
${ }^{8}$ Graham W. J. Beal, "What's the Big Idea? Rethinking the Permanent Collection," in Remix: Changing Conversations in Museums of the Americas, edited by Selma Holo and Mari-Tere Álvarez, 172-79, University of California Press, 2016, http://www.jstor.org/stable/10.1525/j.ctt19rmbt3.36.

${ }^{9}$ Randy Kennedy, "'Grand Bargain' Saves the Detroit Institute of Arts," The New York Times, November 07, 2014, accessed February 28, 2018, https://www.nytimes.com/2014/11/08/arts/design/grand-bargain-saves-the-detroit-institute-of-arts.html.

10 Randy Kennedy, "'Grand Bargain' Saves the Detroit Institute of Arts." The New York Times. November 7, 2014. Accessed June 30, 2017. https://www.nytimes.com/2014/11/08/arts/design/grand-bargain-saves-the-detroit-institute-of-arts.html

11 Neal Rubin, "DIA on Track to Self-sufficiency." The Detroit News, May 14, 2014. Accessed July 5, 2017. http://www.detroitnews.com/story/entertainment/arts/2017/05/14/dia-millage-endowment/101696740/.

12 Laura A. Reese et al., "It's Safe to Come, We've Got Lattes': Development Disparities in Detroit," Cities 60 (2017): doi:10.1016/j.cities.2016.10.014.
} 
anywhere." Under DIA's current director Salvador Salort-Pons's leadership, the museum aims to contribute to a more equitable recovery by embracing and reflecting Detroit's innate diversity, inside and outside its walls. But the process of building trust with historically excluded communities takes time. As Ken Morris, manager of evaluation and research, noted "I think DIA is in a place where they're thinking about the difference between diversity and inclusion and equity. But organizations are like people in that they have some idea of what needs to be done, but doing that is not easy and it's messy. So for me it's a great thing to even be in an organization that says, 'We want to connect with the African American community.' For me that's a significant change in where the organization has been and where it is now."13

\section{Reflecting Detroit: Inside and Out}

The Detroit Institute of Arts has a higher degree of representational diversity in terms of race and ethnicity than the broader art museum field, not only at the overall staff level, but also among intellectual leadership positions, categorized as educators, curators, conservators and senior administrators. However, when studying racial/ ethnic concentrations by job position within DIA, inequities are visible, and the museum's current leadership is working to address them.

Salort-Pons explained that the museum's previous administration struggled to confront issues of diversity, equity, and inclusion in the face of threats to the institution's sustainability, "Graham's DIA lived under constant financial pressure. The museum had to lay off people in 2009, and then there was the [city] bankruptcy, so this museum was only surviving, and when you're only battling an external threat, it is difficult to look internally and try to change things." With DIA on more solid financial footing, and with new leadership, the museum is actively pursuing initiatives to make it more representative of the city and surrounding area it serves. But his ambitions for the museum push beyond representational diversity; Salort-Pons is working to realize a vision of DIA as a public square. ${ }^{14}$

\footnotetext{
${ }^{13}$ Morris has worked in the private sector and academia in the region. He is African American and has lived in Detroit since childhood.

14 Mark Stryker, "New DIA Director Salvador Salort-Pons Talks Priorities," Detroit Free Press, October 6, 2015, accessed July 5 , 2015, https://www.freep.com/story/entertainment/arts/2015/10/06/new-dia-director-salvador-salort-pons-talks-priorities/73471582/.
} 


\section{Staff Diversity: First and Third Floor}

In 2015, the Art Museum Staff Demographic Survey found that of the 181 participating museums, 72 percent of overall staff identified as white non-Hispanic, while 28 percent identified as people of color. Among staff working as curators, conservators, educators, and senior administrators-those job types categorized as "intellectual leadership"these proportions were even more homogenous, with 84 percent identifying as white non-Hispanic, 6 percent as Asian, 4 percent as black or African American, and 3 percent as two or more races..$^{15}$ By comparison, DIA has achieved relatively more racial and ethnic diversity than the broader field, as can be seen in Figures 1 and 2.

When considering representational diversity in relation to the museum's environment, a host of complexities emerge. As shown in Figure 1, DIA's staff is 53 percent white nonHispanic, 39 percent black or African American, with 9 percent comprising Asian and Hispanic employees and employees identifying as two or more races. Among its intellectual leadership, these underrepresented groups are also employed at a higher rate than in the broader field, as seen in Figure 2, with 71 percent white non-Hispanic staff, 15 percent black or African American, and 14 percent Asian, Hispanic, and two or more races.

\footnotetext{
${ }^{15}$ Roger Schonfeld, Mariet Westermann, and Liam Sweeney, "The Andrew W. Mellon Foundation Art Museum Staff Demographic Survey," July 28, 2015, accessed December 5, 2017, https://mellon.org/media/filer public/ba/99/ba99e53a-48d5-4038-80e166f9ba1c020e/awmf museum diversity report aamd 7-28-15.pdf.
} 
Figure 1: DIA All Staff Race/ Ethnicity

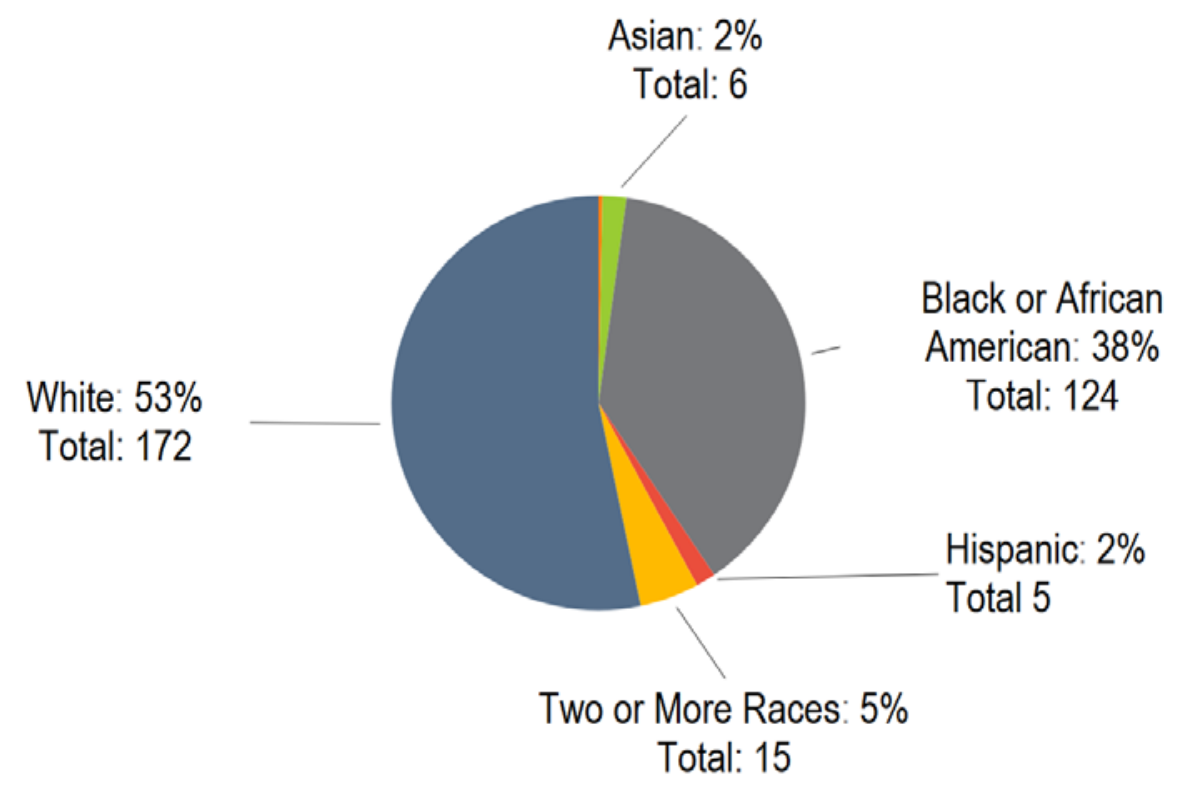

Figure 2: DIA Intellectual Leadership Demographics

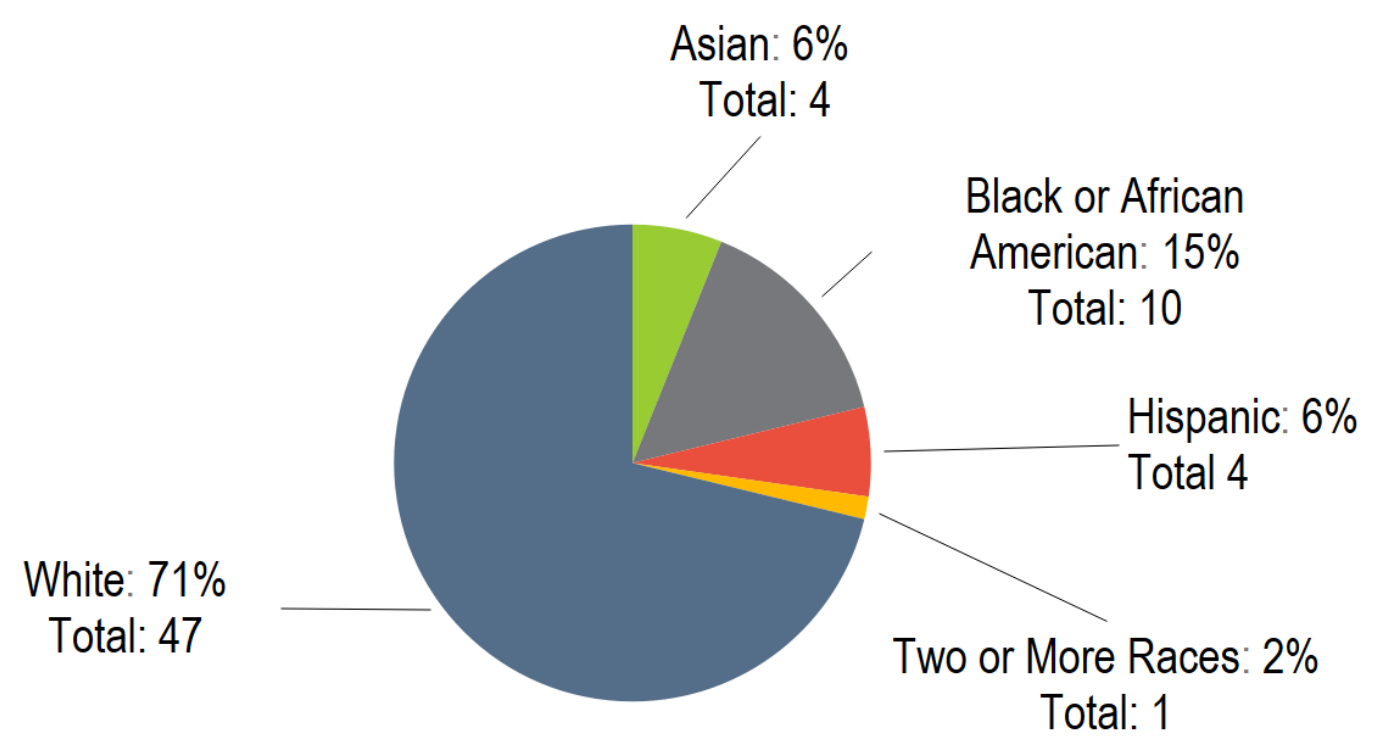


Despite its relatively higher levels of diversity compared to the national averages, some staff at the museum expressed surprise that DIA had been selected to participate in the museum case studies for its diversity. As some interviewees pointed out, the museum is far from representing the demographics of the city of Detroit, which was 83 percent black or African American in the 2010 census. Rather, DIA more closely mirrors the demographics of Oakland, Macomb, and Wayne Counties-the tri-county area that funds the millage - and which are, respectively, 14 percent, 12 percent, and 39 percent black or African American. ${ }^{16}$ But relative to the city of Detroit, which is a part of Wayne County, African Americans remain underrepresented in overall staff and in intellectual leadership positions. The city's demographics are more closely represented in front-line positions, such as security, facilities, and the museum store (see Figure 3).

Figure 3: DIA Security, Facilities, and Store Demographics

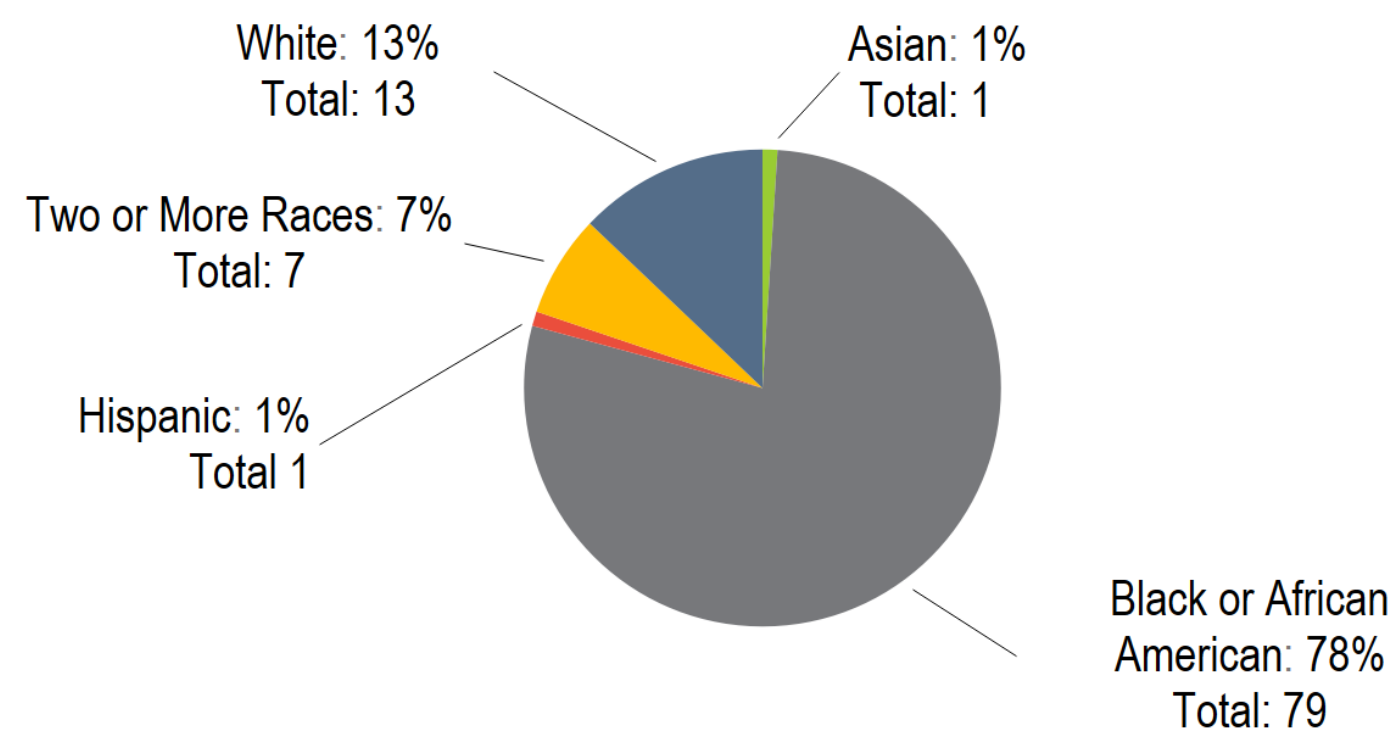

While DIA may be more diverse than other American art museums, there is still a substantial gap in its representation between the front-line staff who work on the first floor and who are majority black, and the leadership staff who have their offices on the

16 "Quick Facts: Michigan," U.S. Census Bureau, accessed December 5, 2017, https://www.census.gov/quickfacts/fact/map/MI/RHI225216\#viewtop. 
third floor and who are majority white. ${ }^{17}$ As one employee explained, "There's a great divide between the third floor and the first floor. We feel that we are not heard up here. They don't come down to the front, they don't listen, they don't see how operations are run. This is the consensus of people working on the first floor-it seems like the ivory tower is making decisions for us." However, this interviewee described that the culture at DIA is changing under the museum's current administration, which is working to bridge the gaps between these parts of the museum.

Salort-Pons discussed some opportunities that he has identified to break down the silos between first and third floor staff. In one recent instance, a security officer moved into the community relations department, then to the marketing department, and is now in charge of in-museum communications, including the museum's signage and public announcements for the programs and exhibitions offered to visitors on the first floor. "The fact that she is a former security officer means she understands the staff and visitor dynamics of the first floor very well. It's a win-win," Salort-Pons said. In another case, a staff member who joined the museum in 2015 in a first-floor operational position completed his bachelor's degree in urban studies at Wayne State University in 2016 and helped to develop the Affinity Business program. This program fosters partnerships between DIA and local businesses to extend membership benefits throughout Detroit and Wayne, Oakland, and Macomb counties. In February 2018, he moved into the newly created development coordinator role. But such transitions are uncommon. While Salort-Pons would like to see a more porous relationship between the third and first floors, thus far these instances of transfer have occurred in an ad-hoc way.

While he is concerned that the division of staff reflects barriers for people of color to access leadership roles in the museum, Salort-Pons also emphasized that he is grateful to have the African American community well represented on the first floor: "I've spoken with some African American community leaders about this, and they've shared that having African Americans represented on the first floor is a good thing. As one mentioned to me, 'I like to see blackness when I am at DIA.'” Acknowledging the inequity in the division between the first and third floors, Salort-Pons also appreciates the diversity that the first-floor staff have brought to the museum, seeing this as a starting point from which he hopes to build a culture of inclusion. An important first step is to recognize the museum's agency in this process. As he explained, "People may think that if you have a job opening and you only receive homogenous applications, it's not the museum's fault or problem. When I see that, I see that this is a problem of my organization. Why are people not interested or why am I not getting a diverse pool? It's

17 Departments other than the four included in intellectual leadership, such as marketing and development, also have their offices on the third floor. 
because the museum is not sending the right messages. We're not making the effort to make sure that all communities know that they have the opportunity to work at DIA." DIA is beginning to implement a Rooney-rule policy, requiring a diverse pool of finalists when hiring for a new position.

\section{Contemporary Curatorial Staff}

DIA has made some recent efforts towards diversifying their curators by increasing the organization's flexibility in hiring contemporary curatorial staff. The results of these efforts reveal lessons that speak to the importance of developing a culture of inclusion, as well as the challenges associated with institutional mentoring and establishing consistent expectations for emerging curators from nontraditional backgrounds.

From 2015 through the end of 2016, the contemporary curatorial department was not staffed. When Salort-Pons succeeded Beale in 2015, the department was being run by cochief curators Nancy Barr and Nii O. Quarcoopome. But there was a lack of staff to properly maintain records and conduct research on the museum's roughly 3,000 contemporary art objects. By the end of 2016, Salort-Pons had hired Laurie Ann Farrell as head of the department. She had previously worked as the director of exhibitions at Savannah College of Art and Design for ten years, and had also spent ten years as a curator for the Museum of African Art.

The museum had budgeted to hire one assistant curator. During the interview process two finalists emerged, both with impressive, though non-traditional qualifications. Taylor Aldridge, a Detroit local who co-founded the online art criticism journal ARTS.BLACK, had recently finished a Master of Liberal Arts in Museum Studies at Harvard. Lucy Mensah completed a PhD in literature at Vanderbilt and was finishing a post-doc at the Metropolitan Museum of Art. 18 "I think Salvador was inspired by both of them," said Farrell. Salort-Pons expanded the department in order to hire them both. To do this, he had to postpone hiring for another position in a different department. By the beginning of 2017, the department was fully staffed for the first time in fifteen years.

Because of the lack of diversity in third-floor staff relative to the population of the city of Detroit, hiring Mensah and Aldridge marked a major step for making DIA more representative of its environment. In terms of representational diversity, it was also significant for the broader field. In encyclopedic museums in the U.S., 87 percent of curatorial positions are held by white professionals, while 1.5 percent are held by black curators, according to data from the 2015 survey of demographics of museum staff. To

${ }^{18}$ Taylor Aldridge is African American and Lucy Mensah is a first generation Ghanaian American. 
put it another way, of the 77 percent (181) of AAMD members who participated in our survey, 90 of them were encyclopedic museums, with an aggregate curatorial staff of 730. Of that total, 634 are white, 96 are people of color, and 11 are black. When DIA hired Mensah and Aldridge, they increased the national percentage of black curators in encyclopedic museums by 18 percent. 19

Much of Mensah and Aldridge's introduction to the museum was unorthodox. SalortPons called them personally to make the job offer. ${ }^{20}$ Their hiring was mentioned in local newspapers as well as an Artforum article. They initially had several opportunities to travel for research and speaking engagements. Within their first year they had organized a show, Making Home: Contemporary Works From the DIA (2017-2018), which received positive local and regional reviews. They were also invited to engage patrons and potential donors. In short, they had been platformed by the museum. Some in the museum felt these opportunities were sending mixed messages about the standard responsibilities of the position. Valerie Mercer, curator and head of the GM Center of African American Art, was surprised to learn how many trips the curators were taking. "I felt the museum was overcompensating," she said. Mercer, an African American woman, has been working as a curator for 25 years, and has been head of the GM Center of African American Art since 2001. "[DIA] was thrilled that there were two young black women as curators in the museum. But they were letting certain criteria become way too lax."

Making Home, which opened in early 2018, was billed as a debut of sorts for the two curators. DIA had been without a curator of their prints and drawings department for nearly two years, during which time the prints and drawings galleries were closed. Around the time of the hiring of Mensah and Aldridge, some board members were pressuring the museum to organize an exhibition and reopen these galleries. Salort-Pons saw this as an opportunity for the new curatorial staff to make a meaningful contribution for the museum and arranged for them to organize the show.

Using two literary texts as a lens (Yaa Gyasi's Homegoing and Isabel Wilkerson's The Warmth of Other Suns), the curators divided the show into themes that both confirmed and challenged assumptions of what home means. The exhibition drew on a broad crosssection of works by artists in the museum's permanent collection, including Carrie Mae Weems, Charles McGee, J asper J ohns, Romare Bearden, Robert Rauschenberg, Tyree

\footnotetext{
${ }^{19}$ The museum has since hired an African American woman to work in the GM Center for African American Art as a research assistant on an upcoming exhibition, Detroit Collects. The position is temporary and will end by late July 2019.

20 Salort-Pons has personally made job offers to other assistant curators as well in cases where he wants to signal that the museum has strong interest in hiring the individual.
} 
Guyton, Glenn Ligon, J ane Hammond, Gregory Crewdson, Hiraki Sawa, and J oanne Leonard. Through this show, the curators familiarized themselves with DIA's permanent collection, drawing on many works that had been held in storage for years. They simultaneously sought to make the exhibition accessible to youth, aware that roughly 70,000 students visit the museum annually. The exhibition was composed of eight thematic areas: childhood imagination, home and community, urbanization, displacement, (in)security, domesticity, melancholy, and the sublime. The show received favorable reviews in local and national publications such as the New York Times, Culture Source, ${ }^{21}$ and Metro Times. ${ }^{22}$
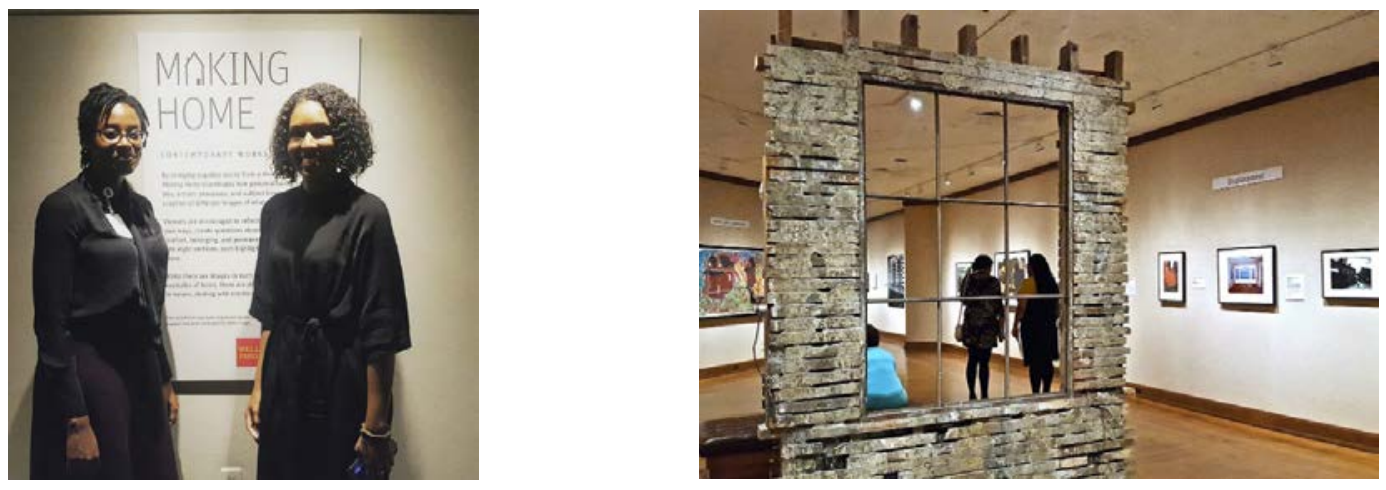

Left Photo: Lucy Mensah (L) and Taylor Aldridge (R) at the opening night celebration of Making Home, credit: Sarah Rose Sharp, Culture Source

Right Photo: Making Home exhibition, view of Urban Extract (1979) by Charles McGee, credit: Sarah Rose Sharp, Culture Source

Making Home (2018) was a success for the museum, but the process of developing the show created tension within the department. Questions and conflicts arose concerning authority over the curatorial process for the show. In the same time period, questions came up about the degree to which Mensah and Aldridge could develop an independent curatorial presence versus acting as representatives of DIA. Following Making Home, some of the opportunities that were initially made available to Mensah and Aldridge ceased as they were instructed to focus primarily on collections management research in preparation for the reinstallation of the contemporary galleries; a significant undertaking

\footnotetext{
${ }^{21}$ Anita Gates, "From 12th Century B.C. to 2017, Art in Startling Variety," The New York Times, March 07, 2018, accessed August 09, 2018, https://www.nytimes.com/2018/03/07/arts/from-12th-century-bc-to-2017-art-in-startling-variety.html; Sarah Rose Sharp, "Home," CultureSource, January 04, 2018, accessed July 24, 2018, https://www.culturesource.org/201801042803/stories/the-dia-snew-contemporary-curators-make-themselves-and-visitors-at-home.

22 Lee DeVito, "New DIA Exhibition Searches for Home," Detroit Metro Times, July 22, 2018, accessed July 24, 2018, https://www.metrotimes.com/detroit/new-dia-exhibition-searches-for-home/Content?oid=7627967.
} 
given the lack of attention paid to the collection over the last two years. The two curators expressed that they were interested and engaged with this research, but felt that the shift, which aligned with a change in the atmosphere of the department, was a way of limiting their voices. Mensah said, "All focus turned to the research for the reinstallation, even though there was a lot we could balance with that." Other curators at the museum saw this development as the inevitable introduction of routine curatorial research, which had been sidelined to this point.

Mensah and Aldridge left the museum shortly after their show closed. Mensah has taken a position as visiting professor in the museum studies department at the University of Illinois, Chicago. Aldridge is pursuing independent projects, focusing on her online publication, and preparing applications for graduate school. Both curators shared in retrospect that they had expected to stay at DIA for a number of years.

A separate issue, but one that contributed to the tension in the department, was related to expectations surrounding the conceptual approach to the reinstallation. Mensah and Aldridge both struggled with what they saw as a lack of appetite for integrating critical race theory and black feminist theory as they conducted research on the reinstallation. Given the nature of these curators' public presence, there was some concern that a more conservative reinstallation might not reflect positively within the artistic and professional communities they are connected to.

Mercer reflected that, over her 17years at DIA, she has had to be strategic in her approach to bringing racial issues into the museum: "Sometimes the way of doing it needs to be softer." Mercer said she tries to emphasize to white audiences that the history of race in America is their history too, in an effort to generate interest, rather than emphasizing differences. "But to be perfectly honest DIA is conservative. It has to do with the culture of Detroit. It's not like being in New York," Mercer said. When talking about racial politics, she says that in her experience audiences can get uptight or even hostile. Farrell considers the museum to be making positive strides towards a more open dialogue around race and gender inequities, citing exhibitions such as the Shirin Neshat retrospective (2013) and 30 Americans, which came to the museum in 2015, as well as a deliberate effort since she arrived at DIA to collect more globally, and to increase the representation of women in the collection.

While the departure of Aldridge and Mensah is in many ways situational, there are some salient lessons for the broader field as museums work toward improving equity, diversity, and inclusion. Sondra J enkins, executive director of organization development and human resources, acknowledged that improvements can be made to the management style that catalyzed their departure. But those challenges are not isolated to the contemporary art department. J enkins shared that the museum, which has reported 
323 staff members in the 2015 demographic survey, struggles with developing middle management skills in a number of departments. More specifically, J enkins thinks the primary lesson for the museum is to be clearer at the outset about the requirements for the position, and set expectations more clearly as to the latitude and timeline for staff to develop an independent role and voice in the museum.

Because of structural barriers to the elite institutions that have traditionally credentialed candidates for competitive curatorial roles in the arts, developing an independent presence can be an alternative form of qualifying oneself for employment in the field. What happens when that independent platform interacts with the established processes and norms of the institution? It is important for a museum to interrogate critically the degree to which these aspects of the candidate's professional identity will, or will not, be embraced as it seeks to establish a culture of inclusivity while diversifying their ranks.

It is not entirely clear to what degree Aldridge and Mensah were hired to perform the standard work of an assistant curator in a department with a large backlog of collections management work, versus playing an intensive role of representing the museum on a national level, while also cultivating local relationships with the arts scene in Detroit. At various points in time these differing expectations collided. In a sense, the museum succeeded in increasing the representational diversity within the department but failed to strike the appropriate level of inclusivity when it established mixed expectations for the role these curators were assuming. Recognizing this, DIA is committed to continuing to diversify the curatorial staff going forward, with an understanding that they will need to address management issues, more fully conceive of the responsibilities these staff will have, and communicate these expectations more clearly in the future.

\section{Paid Internships}

In a 2016 New York Times op-ed, Ford Foundation president Darren Walker ${ }^{23}$ spoke to broad concerns that unpaid internships create a significant barrier in competitive fields for low income candidates: "America's current internship system, in which contacts and money matter more than talent, contributes to an economy in which access and opportunity go to the people who already have the most of both." 24 Unpaid internships have become an industry standard, especially for curatorial staff. Aldridge described her own experience entering the field: "If I was offered an internship at a prestigious

\footnotetext{
${ }^{23}$ Walker spearheaded the philanthropic rescue of DIA's collection in 2012: Randy Kennedy, Monica Davey, and Steven Yaccino, "Foundations Aim to Save Pensions in Detroit Crisis," The New York Times, January 13, 2014, accessed January 18, 2018, https://www.nytimes.com/2014/01/14/us/300-million-pledged-to-save-detroits-art-collection.html.

${ }^{24}$ Darren Walker, "Opinion: Internships Are Not a Privilege," The New York Times, July 05, 2016, accessed January 17, 2018, https://www.nytimes.com/2016/07/05/opinion/breaking-a-cycle-that-allows-privilege-to-go-to-privileged.html.
} 
institution, I'd have to pause because I need a paid job. I don't have wealthy parents to lean on, and for people of color it's difficult to take on an unpaid internship."

DIA has invested in a paid internship program, hoping that a commitment to the professional development of young museum employees will diversify the candidate pool while maintaining the high quality of its staff. This past summer, DIA welcomed its inaugural class of paid interns. The program targets college-level students from Wayne, Macomb, and Oakland Counties and is meant to provide them with a broader understanding of the different types of jobs available within museums. Additionally, two paid internships are dedicated to providing students from underrepresented racial and ethnic groups with training in intellectual leadership roles through the Nettie Seabrooks Gateway internships. Many organizations struggle to fund their internship programs, but for Salort-Pons, "It's not a sacrifice. We are doing it because we see a problem and we want to be a museum that helps in the solution, and one approach to the solution is building the pipeline." 25 While these five internships are now paid, the museum still takes on some unpaid interns. In May of 2018, the museum received $\$ 100,000$ for two years of funding for an expanded paid internship program. As a result, DIA will add eight new paid internship positions.

\section{Institutional Manners: Hosting vs. Visiting}

DIA is a uniquely public institution. As the museum struggled with severe budget deficits in 2012, the tri-county area voted to fund the museum through a millage, which will cost the tax payers roughly $\$ 15$ for every $\$ 150,000$ of a home's market value. While some other museums such as the Minneapolis Institute of Arts and the St. Louis Art Museum also rely on property taxes for a portion of their revenue, the millage is more significant for DIA given that the museum is in the process of building its operating endowment and does not receive financial support from the city or state. It provides the museum with over \$20 million per year, the majority of its budget, and has granted DIA more financial security than it has enjoyed in decades. ${ }^{26}$

${ }^{25}$ Roz Edward, "DIA Launches Internship Program for College Students," Michigan Chronicle, July 24, 2017, accessed December 5 , 2017, https://michronicleonline.com/2017/07/24/dia-launches-internship-program-to-support-professional-and-career-developmentfor-college-studentsl.

${ }^{26}$ Patricia Cohen, "Suburban Taxpayers Vote to Support Detroit Museum," The New York Times, August 08, 2012, accessed January 17, 2018, http://www.nytimes.com/2012/08/09/arts/design/detroit-institute-of-arts-county-millage-tax-approved.html. 
As part of the millage, DIA has extended free admission to all tri-county residents, and offers discounts for ticketed exhibitions. ${ }^{27}$ DIA also pays for buses for school field trips, has extended programs for seniors, and expanded professional development programs for teachers. Furthermore, the museum offers a community partnership program and works with non-profit organizations across the tri-county area offering a number of cultural activities to the residents beyond the walls of DIA.

Since the millage DIA has explored other ways to reach visitors. The four-acre front plaza and the grounds between Woodward Ave and J ohn $\mathrm{R}$ Street are being reimagined as a gathering place for locals. At present, the grounds receive little public use, despite being situated in a prime location in midtown. Through community evaluation efforts DIA has learned that potential visitors see the exterior and grounds of DIA as, in their words, "impermeable," an "ivory tower," and "standing separate from our community." With grants from the NEA and William Davidson Foundation, the museum is planning to transform this space into a cultural hub and a public square, an idea largely inspired by Salort-Pons' upbringing in Spain: “I felt that Detroit didn't have a gathering place, a place where everybody meets, a place that is safe and inclusive, where you go sort of like a magnet. I always felt that the museum had that gathering power." He sees the museum's collection not as an endpoint but as the point of departure, from which community engagement can grow.

The museum's renewed commitment to the community has had the effect of sharply increasing its number of visitors - attendance was up 50 percent the first year of the millage, and has continued to rise. ${ }^{28}$ But DIA still struggles with diversifying its visitors. Data from exit surveys spanning from J uly 2016 to J une 2017 indicate that 66 percent of overall visitors came from Detroit and the surrounding tri-county area, with an overall audience that was 76 percent white. Only nine percent of visitors in this time period were black or African American, ${ }^{29}$ compared to an average of 22 percent who identify as such in the tri-county area. ${ }^{30}$ Since the millage, DIA has established goals for attendance

\footnotetext{
${ }^{27}$ The museum often seeks diverse audiences through special exhibitions. While the fee can create an additional barrier for these populations, audience evaluation has shown much higher attendance by people of color to ticketed exhibitions such as 30 Americans.

${ }^{28}$ Paul Kampe, "Detroit Institute of Arts Marks One Million Visitors Since Passage of Regional Tax," Oakland Press, February 2, 2016, accessed December 14, 2017, http://www.theoaklandpress.com/general-news/20160202/detroit-institute-of-arts-marks-onemillion-visitors-since-passage-of-regional-tax.

29 "DIA Visitor Satisfaction Survey," 2017, The Detroit Institute of Arts.

30 "QuickFacts: Michigan," U.S. Census Bureau, accessed December 5, 2017, https://www.census.gov/quickfacts/fact/map/MI/RHI225216\#viewtop.
} 
demographics, aiming for the museum's audiences to reflect the racial/ ethnic composition of the tri-county area. ${ }^{31}$

\section{Reflecting Our Community}

Increased engagement with the communities in the tri-county area is also driven in large part by the millage and its mandates for increased collaboration. In addition to free admission for tri-county residents, the millage funds a school program that brings 70,000 students to the museum annually. It expands programs for seniors as well as community partnerships. "The millage made the museum establish a deeper and more authentic relationship with the community," Salort-Pons says. Museum staff are aware that some in the community are concerned that efforts towards inclusion are temporary, and if the millage is not renewed, outreach efforts will change. But Salort-Pons is confident that the change is permanent. One of the ways this is being institutionalized is through the Reflecting Our Community (ROC) initiative.

Reflecting Our Community, an initiative that aims to help DIA cultivate an audience that more accurately reflects the demographics of the tri-county area, was formed in 2016 and has adopted an approach which tackles staff, program, and audience diversity. Ken Morris, manager of evaluation and research, and J ennifer Czajkowski, VP of learning and audience engagement, co-chair the committee that includes a cross-departmental group of staff members. It has identified engagement with the African American community as a priority, given that 22 percent of metro Detroiters are African American and DIA's audience is roughly half that figure. ${ }^{32}$

DIA hopes to leverage and grow previous investments in African American art, primarily the General Motors Center for African American Art, which was endowed in 2000 and has been run by curator Valerie Mercer since 2001. While the General Motors Center signals a major investment the museum has made in African American art, some in the museum feel conflicted about keeping the work of black artists in a separate gallery. As one employee said, "When I was younger I did appreciate coming to this museum and being able to find galleries that were specifically dedicated to African American artists. But now that I'm older, my view has definitely changed, and now I see it as a segregation of sorts." Revamping this center with a three-year plan to strengthen art acquisitions,

\footnotetext{
31 This data is collected in quarterly visitor satisfaction surveys, which gather responses from around 2,000 adult visitors every year, yielding a three percent margin of error.

32 The Latino, Asian, and Arab American communities are also part of ROC and DIA's commitment to engage the large variety of metro Detroit audiences.
} 
exhibitions, and programming is one of five key strategies that DIA has implemented through the ROC committee. The first step as part of this plan was the art acquisition of Bird by David Hammons. DIA paid seven figures for the work, making it the first time the museum supported an art purchase at that financial level for its African American collection 33

Other initiatives include building partnerships in Detroit's black community using research and evaluation to align DIA programming, improve marketing and communications efforts, and focus on staff development and equitable practices like paid internships. These efforts focus largely on bringing historically excluded communities into the museum and making them feel welcome. But the museum has some work to do to establish a presence outside its walls if it hopes to build lasting trust with the people of Detroit. As Sondra J enkins, executive director of organization development and HR put it, DIA has historically had a "seagull kind of strategy, where we've reached out to, let's say, an African American community for Black History Month, and we descend on this community with programming and say 'we're your best friends, and we've got all this stuff,' it's almost overwhelming. And then come March, it's like you don't hear from the museum again." J enkins hopes the ROC initiative will prevent this "seagull" approach to community relations by building an ongoing presence outside the museum.

Some efforts are underway to manifest this change. For instance, the Inside|Out program offers reproductions of works of art placed in key areas of city of Detroit and the tri-county area. "We install a reproduction of a Van Gogh in a public space with a label, and it becomes sort of a public art work," Salort-Pons said, describing the program. "We offer walking tours and bike tours. Sometimes I personally provide a tour of the Inside|Out reproductions. We walk around the city and talk with the community. At the end of the tour I'm no longer the one presenting the works-everyone is talking about the art, about what it means to them. We are now partnering with the Charles H. Wright Museum of African American History on this program, and we make sure we take into consideration the particular demographics of the locations when we choose the reproductions."

After hearing Salort-Pons speak about the Reflecting Our Communities initiative, Sharon Harrell, then an outreach coordinator, wrote a proposal for a position of coordinator of community programs, which was accepted by senior administration. In this role, she began working in the community relations department and focused on building

\footnotetext{
33 Franz Lidz, "This \$1.4 Million "Bird" Makes an African-American Art Collection Soar to New Heights," Smithsonian.com, October 26, 2016, accessed March 03, 2018, https://www.smithsonianmag.com/arts-culture/this-million-bird-makes-african-american-artcollection-soar-to-new-heights-180960914/.
} 
relationships with underserved communities in Detroit and DIA. As Harrell puts it, it's a new phenomenon in local African American communities to see the museum trying to engage. "They want a more consistent presence," Harrell said, "They are concerned about the depth of the project that the museum is able to offer, they want things like a hub in their communities, where we offer consistent art making or consistent talks and presentations outside of the museum. They also want to make sure that this is going to continue, that the museum's presence isn't going to be just for a short time period and then forgotten."

Recently, Harrell organized a community conversation at the museum. Salort-Pons was encouraged by the public participation: "People are excited about this, a number of people from the communities we're now reaching participated. They offered various suggestions to better our communication with them, including ideas to improve our website." One of those ideas was to have some of DIA's programs, such as the recent lecture by Mark Bradford, streamed online and recorded to increase access. "DIA quickly implemented this suggestion and we were able to live-stream online poet laureate Tracy K. Smith's lecture and reading on February 2 as part of the events celebrating Black History Month. It was a way for us to let them know that we heard them and wanted to do better as soon as possible." The meeting, which was on a Saturday, was attended by J ennifer Czajkowski, vice president of learning and audience engagement, Harrell, Salort-Pons, and Morris. But outside of the museum's leadership staff attendance was low, indicating that more needs to be done to turn the desire for community engagement into action.

\section{Board Diversity}

The Detroit Institute of Arts has had some recent success diversifying its board. In December 2016, the museum added four board members, three of whom were people of color. Two of those three were women. ${ }^{34}$ This is part of a larger plan led by Salort-Pons and Rhonda Welburn, chair of DIA's Governance and Nominating Committee. The museum has committed to diversify its board by 2020 to reflect the demographic makeup of the three counties which support DIA.

In one instance, Salort-Pons discussed how he was able to recruit a member of the Indian American community to the board of directors by utilizing his Talent and Diversity Committee (TDC) and through continued engagement with the community. The committee consists of members from a variety of racial and ethnic backgrounds with

34 "Detroit Institute of Arts Announces Four New Board Members," Detroit Institute of Arts, accessed December 5, 2017, https://www.dia.org/about/press/news/detroit-institute-arts-announces-four-new-board-0. 
the goal of identifying individuals to diversify the board's pipeline. Because DIA was having trouble achieving Indian representation on the board, Salort-Pons directly engaged them by organizing a reception at the museum with the help of an Indian member of the TDC, to which they invited other members of their community for a tour of the Indian art galleries at DIA. For many, this was the first time that they had been to the museum.

Recognizing the importance of hospitality in Indian culture and at the informal request of some members of this community, Salort-Pons followed up this first engagement by suggesting that he and his wife Alex cook a meal for nearly 70 people. The intention was to socialize and also to show the Indian community the museum's current plans to reinstall DIA's Indian galleries. The director continued these efforts with other events at DIA, including guided visits of some of the temporary exhibitions. Eventually a seat on the board became available and he was able to recruit one of the leaders in this community, Padma Vattikuti, an art collector and philanthropist. "Padma and her husband Raj are some of the kindest people I know. She loved the fact that we were trying to bring the Indian community to DIA," Salort-Pons said, "So, we met with her and asked if she would like to be part of the board of directors, and she said 'yes because of what you are doing, you are reaching out into our community. '”

\section{The Breakfast Club}

As Lowery Stokes Sims says in her introduction to Something to Say: The McNay Presents 100 Years of African American Art, "Despite the frenzy of market dynamics that have infected the global art world, identifying and finding the art of African Americans has been a specific act of archaeology." This is the case in Detroit, which has had an exciting cultural scene over the last several decades largely obscured by narratives of urban decline. While DIA curators continue to undertake local studio visits and plan to install more works of local artists in the galleries, the museum has also recently sought an engagement with the existing informal art groups in Detroit, which is doing a great deal to build trust within an existing community of artists and connoisseurs who have not historically felt welcome at DIA.

In August of 2017, Salort-Pons hosted a dinner at his home for a group of African American art collectors loosely affiliated with a local art-lovers group known as the Breakfast Club. In the middle of dinner, he gave the floor to some of the most prominent collectors of African American art in Detroit, who have built impressive collections over the last few decades, to discuss the possibility of bringing pieces from their collections together in order to, for the first time at DIA, provide the city with an exhibition that documents the cultural production and collecting practices of its own artists and residents. "This exhibition will be historic for Detroit," Salort-Pons says. "The museum 
for the first time is paying attention to these collectors who've been collecting for many years. It's also historic because we're going to publish a catalog that will record stories and provide voices to these collectors. They're going to show their pieces at DIA, for which they are very excited."

The group of roughly a dozen collectors represent prominent patrons of Detroit arts, including two DIA board members. Among the group includes Henry Harper and Harold Braggs, J r., the founding members of the Breakfast Club. In conversation, Harper shared how refreshing it was to see DIA connecting with this group. "For fifteen years I've asked the museum to organize this exhibition but there was always some sort of financial impediment. We asked Salvador once and he said 'Let's sit down and talk about it and make it happen.'”

While many of these collectors have been acquiring work for decades, the Breakfast Club was formed in 2009 when Henry Harper and Harold Braggs, J r. began meeting in a diner in North West Detroit every Monday to discuss the art market. Harper describes the activity as the "afterglow," spending time after breakfast talking about art. The Breakfast Club was as much about guiding and mentoring emerging artists interested in selling work as it was about acquiring art, Harper said. Eventually word spread that some collectors were available Sunday afternoons on Livernois Ave, and artists began to bring their work to the diner and presented to potential buyers. "As a result, we grew and now it's like a church, people are so energetic, 150 artists show up every Monday at 5PM." Sales of work range from $\$ 50$ to $\$ 18,000$.

In February of 2018, DIA served as host to the Breakfast Club; local artists presented work to collectors in the museum. To Harper, this was a turning point: 'It's hugely significant that DIA is partnering with us. Nobody ever cared about us before. It's heartwarming, endearing, special, incredible, emotional, for a class A museum to care about the community that it's in. It felt like negligence before." This is not a resurgence of African American art in Detroit, Harper says. "It's just new that DIA is paying attention to it." 


\section{Determining Meaning: Interpretation, Evaluation, and Curation}

In November 2007, 90 galleries were reinstalled at the Detroit Institute of Arts with nearly 5,000 objects from the museum's permanent collection. This ambitious reinstallation reflected an adaptation of Beverly Serrell's "Big Idea” exhibition method, in which art objects are selected to align with a unified interpretation of a theme. ${ }^{35}$ The reinstallation was created through a collaborative process with curators and interpreters, a process that the museum has carried forward in its current exhibition practices.

The transformation came out of an emergency. Failing walls, asbestos issues, and problems with crowd circulation led to a large-scale construction project, which created an opportunity to refresh the galleries. Under the leadership of former director Graham Beal, the reinstallation team developed guidelines for the museum's new approach to exhibitions: "Interpretation is better understood as a means of communication between the museum and its audience, in which 1) the audience is encouraged to engage in satisfying experiences; and 2) the museum deepens its understanding of its audience for the purpose of better serving its visitors." 36 The reinstallation served as a turning point for DIA. The museum has increasingly identified itself as being visitor-centered since it reopened in 2007, a characteristic of its mission that has been reinforced by the millage and grand bargain. Still, the reinstallation did not succeed in connecting with audiences in the city of Detroit. While the collection may have grown more accessible to the casual museum goer, that audience has demographically remained homogenous.

Interpretation and evaluation are both relatively new approaches in the art museum field, and DIA has been a leader in both areas. The reinstallation integrated interpretive and evaluative processes deeply in the presentation of its collection. As Ken Morris, manager of evaluation and research, noted, "Within the art museum community, DIA has always been considered to be at the forefront of the [evaluation] movement." Morris has been involved in evaluation in the museum for fifteen years, beginning prior to the reinstallation. His team conducts surveys of visitors to help the museum better understand their experience with exhibitions. In some cases, Morris and his colleagues also conduct research outside the museum walls to better understand the communities they are trying to reach. He observed that this research serves two functions: the team is able to collect feedback from community members, and, "J ust by virtue of doing that

\footnotetext{
35 Beverly Serrell, Exhibit Labels: An Interpretive Approach, New York: Rowman \& Littlefield, 2015.

36 David W. Penney, "Reinventing the Detroit Institute of Arts: The Reinstallation Project 2002-2007," Curator: The Museum Journal 52, no. 1 (2009): doi:10.1111/j.2151-6952.2009.tb00331.x.
} 
there's a level of community outreach." Whether or not it's intentional, Morris recognizes that conducting research outside DIA's walls helps to make the museum more visible. When asked about the museum's new focus on underserved populations, Morris commented that, 'When we help make people aware of what's here, and help make people comfortable when they're here, then we have them, so to speak. They were people that we weren't working to connect with before, and now we are working to connect with them."

One of the strategies DIA has adopted for connecting with underrepresented communities is to show more art that reflects their cultures. In some cases this has involved new collaborations and partnerships, expanding the network of Detroit-based organizations connected to the museum.

\section{Detroit '67}

In 2017, one such partnership centered around the museum's efforts to reflect on the fiftieth anniversary of the 1967 rebellion. The museum collaborated with the Detroit Free Press' Freep Film Festival to produce 12 $2^{\text {th }}$ and Clairmount. The documentary developed from festival co-founders Steve Byrne and Kathy Kieliszewskis' interest in capturing the historical moment of the summer of 1967 half a century later, and combines an oral history of the events leading up to and after the rebellion with the perspectives of residents living in Detroit at the time, as depicted through their home movies. Byrne and Kieliszewski helped DIA solicit this home footage and managed the cataloging and digitization of the 700 reels sent in by residents. "It has been an unusually big success for us," Byrne said of the film, which had been viewed by about 9,000 people in Detroit as of the site visit, "and DIA was a huge part of this project coming together."

In addition to $12^{\text {th }}$ and Clairmount, the museum commemorated the anniversary of the 1967 rebellion with an exhibition entitled Art of Rebellion (2017). Art of Rebellion invites viewers to reflect on the social and political issues and shared history and culture of the African American community as captured by African American artists and activists who produced work individually and in collectives during the Civil Rights Movement up to the present day. ${ }^{37}$ The exhibition, curated by department head of the General Motors Center for African American Art Valerie Mercer, not only portrays historical discrimination and endemic violence perpetrated against African Americans, but also pride in the community's identity and accomplishments. DIA collaborated on this project with The Charles H. Wright museum of African American History, which organized its

37 "Art of Rebellion: Black Art of the Civil Rights Movement," Detroit Institute of Arts, accessed December 7, 2017, https://www.dia.org/art/exhibitions/art-rebellion-black-art-civil-rights-movement. 
own exhibition: Say It Loud: Art, History, Rebellion (2017). Both exhibitions complemented each other and were part of a unified effort. It was the first time that DIA partnered with the Wright Museum. Now, both institutions are developing a three-tofive year strategic plan to continue working together.

\section{Evaluation}

Morris's evaluation team conducted a visitor engagement survey during an eight-day period for Art of Rebellion and collected responses from 513 visitors of the 50,692 who attended. More than a third of respondents had never visited the museum before, with almost as many saying that the exhibition and its content influenced their decision to visit. The survey allowed the museum to measure visitors' reactions to the exhibition, and track demographic variables, helping them measure how certain exhibitions connect with various communities. For instance, after Morris's team analyzed and coded free text responses asking respondents if anything had a strong positive or negative effect on their visit, the plurality (17 percent) of the 308 recorded comments described the exhibition as being "thought provoking and emotional." Respondents were 40 percent male, 60 percent female, with 72 percent holding a college or graduate degree. Eighty-four percent visited in a group (the average size: 2.8). Respondents were 72 percent white/ European, 16 percent African American, 7 percent Hispanic/ Latino.

Art of Rebellion was also evaluated in relation to a group of other exhibitions, yielding some interesting results that could help guide the museum's thinking as it works toward a goal to have its audience reflect the demographics of the tri-county area. For instance, comparisons show that audience demographics differ substantially by exhibition. Rembrandt and the Face of J esus (2012) attracted an audience that was 89 percent white and 5 percent African American, while 30 Americans (2009) drew an audience that was 51 percent white and 41 percent African American. While the nine exhibitions in the comparison group drew crowds with average ages spanning 45 to 54, Art of Rebellion attracted a younger crowd, with an average age of 41 . Art of Rebellion attracted significantly fewer museum members than the nine comparison exhibitions; twelve percent of the exhibition's audience were members, whereas the comparison group ranged from 27 percent to 43 percent. And Art of Rebellion drew the lowest number of Michigan residents. While 25 percent of visitors to 30 Americans were from Detroit, only 10 percent of visitors to Art of Rebellion were from the city.

During a Reflecting Our Community committee meeting, members discussed expanding the visitor engagement survey to include D-Cyphered (2017), a recent photography exhibition that showcases Detroit's hip-hop scene. The committee expressed interest in conducting a visitor survey for the exhibition, in part to build a deeper understanding of the ways the museum's exhibition program affects the demographics of the audience. D- 
Cyphered consists of 75 portraits of Detroit hip-hop artists, the majority of them African American, that were shot by Detroit native J enny Risher between 2015 and 2017.

Morris described how even in the early stages of planning an exhibition, the visitor has to be taken into consideration: "Is it something that's going to resonate with them? Is it something that's going to fit their needs? What are their needs?" Evaluations are most easily collected through exit surveys and response boxes that have been scattered throughout various galleries, but this method doesn't collect feedback from people who do not come to the museum in the first place. "If we're trying to reach local stakeholders, sometimes those people aren't coming to the museum so we have to go where they are," Morris explained. He listed other outreach methods such as web surveys, social media sites, and personal networks that are used to connect to targeted communities. Although he expressed that limited capacity and resources can affect the amount of outreach DIA is able to do, the continued use of evaluation and the willingness to engage directly with underrepresented communities demonstrates another way that the museum is working to diversify its audience.

\section{Conclusion}

Over the last fifteen years the Detroit Institute of Arts has been dramatically reshaped, both by external forces and through its deliberate efforts to be a visitor-centered museum. The 2007 reinstallation transformed the museum, changing the course not only of the composition of its galleries, but also of the museum's operations. The grand bargain was an unprecedented case in which an elegant solution was found to a catastrophic threat, preserving the most prized works in the museum's collection for the public as well as securing the pensions of public employees. The millage has granted the museum an unusual degree of financial stability and has galvanized a commitment toward inclusion and equity for the tri-county area.

DIA continues to grapple with issues of representation, particularly in relation to the city of Detroit, which still struggles acutely with the repercussions of the racial tensions in the 1960s. As the museum implements strategies to address the ongoing lack of representation of local Detroit communities from its staff, exhibitions, and audience, it faces difficult realities. As of our site visit, none of the museum's education staff were African American. The museum's black visitorship remains substantially lower than the 22 percent target the current administration has set, which aims to reflect the tri-county population. Two recently hired African American curators left the museum following internal tension with their manager. And efforts to build trust in local communities are in early stages, requiring ongoing efforts before meaningful change will be realized. 
In spite of these challenges, the Detroit Institute of Arts demonstrates a commitment to realizing this desired change, not only through the leadership's vision to make the museum Detroit's public square, but also through a number of tangible administrative choices that show a commitment behind the rhetoric. Moves toward a paid internship model shows a financial commitment to providing entry-points for diverse emerging professionals. Bringing local artists into DIA's permanent galleries and an emerging partnership with the Breakfast Club are indicators of a meaningful shift in how the museum engages local culture. Steered with a commitment to evaluation and iterative improvements through evidence, the Detroit Institute of Arts is learning from its past and making progress toward a vision of becoming Detroit's public square. 


\section{Appendix}

\section{Case Studies in Inclusion, Diversity, and Equity among AAMD Member Art Museums}

Three years ago, Ithaka S+R, the Andrew W. Mellon Foundation, the Association of Art Museum Directors (AAMD), and the Alliance of American Museums (AAM) set out to quantify with demographic data an issue that has been an increasing concern within and beyond the arts community: the lack of representative diversity in professional museum roles. Our analysis found there were structural barriers to entry in these positions for people of color. After collecting demographic data from 77 percent of AAMD member museums, we published a report sharing the aggregate findings with the public. In her foreword to the report, Mariët Westermann, executive vice president for programs and research at the Mellon Foundation, noted, "Non-Hispanic white staff continue to dominate the job categories most closely associated with the intellectual and educational mission of museums, including those of curators, conservators, educators, and leadership." 38 While museum staff overall were 71 percent white non-Hispanic, we found that many staff of color were employed in security and facilities positions across the sector. In contrast, 84 percent of the intellectual leadership positions were held by white non-Hispanic staff. Westermann observed that "these proportions do not come close to representing the diversity of the American population."

The survey provided a baseline of data from which change can be measured over time. It has also provoked further investigation into the challenges of demographic representation in this sector. Many institutional leaders are growing increasingly aware of demographic trends showing that in roughly a quarter century, white non-Hispanics will no longer be the majority in the United States, whereas ten years ago the white nonHispanic population was double that of people of color. ${ }^{39}$ This rapid growth indicates that institutions will need to be intentional and strategic in order to be inclusive. To aid these efforts we set out to understand the following: What practices are effective in making the American art museum more inclusive? By what measures? How have museums been successful in diversifying their professional staff? What do leaders on issues of social justice, equity, and inclusion in the art museum have to share with their peers?

\footnotetext{
38 Roger Schonfeld, Mariët Westermann, and Liam Sweeney, "Art Museum Staff Demographic Survey," Andrew W. Mellon Foundation, July 29, 2015, https://mellon.org/media/filer public/ba/99/ba99e53a-48d5-4038-80e166f9ba1c020e/awmf museum diversity report aamd 7-28-15.pdf.

39 William H. Frey, "A Pivotal Period for Race in America," In Diversity Explosion: How New Racial Demographics Are Remaking America (Washington DC: Brookings Institution Press, 2015), 1-20, http://www.jstor.org/stable/10.7864/j.ctt6wpc40.4.
} 
Using the data from the 2015 survey, we identified 20 museums where underrepresented $\mathrm{racial} /$ ethnic minorities have a relatively substantial presence in the following positions: educators, curators, conservators, and museum leadership. We then gauged the interest of these 20 museums in participating, also asking a few questions about their history with diversity. In shaping the final list of participants, we also sought to ensure some breadth in terms of location, museum size, and museum type. Our final group includes the following museums:

- The Andy Warhol Museum (Pittsburgh)

- Brooklyn Museum

- Contemporary Arts Museum Houston

- Detroit Institute of Arts

- Los Angeles County Museum of Art

- Museum of Contemporary Art, Chicago

- Spelman College Museum (Atlanta)

- Studio Museum in Harlem. ${ }^{40}$

We then conducted site visits to the various museums, interviewing between ten and fifteen staff members across departments and levels of seniority, including the director. In some cases, we also interviewed board members, artists, and external partners. We observed meetings, attended public events, and conducted outside research.

In the case studies that follow, we have endeavored to maintain an inclusive approach when reporting findings. For this reason, we sought the perspectives of individual employees across various levels of seniority in the museum. When relevant we have addressed issues of geography, history, and architecture to elucidate the museum's role and context in its environment. In this way we show the museum as a collection of people - staff, artists, donors, public. This research framework addresses the institution as a series of relationships between these various constituents.

We hope that by providing insight into the operations, strategies, and climates of these museums, the case studies will help leaders in the field to approach inclusion, diversity, and equity issues with a new perspective.

\footnotetext{
40 We focused on people of color for measuring diversity for two reasons: (1) In the 2015 art museum demographic study, we received substantive data for the race/ethnicity variable, unlike other measures such as LGBTQ+ and disability status, which are not typically captured by human resources, and (2) in the study we found ethnic and racial identification to be the variable for which the degree of homogeneity was related to the "intellectual leadership" aspect of the position (i.e., curator, conservator, educator, director). We are alert to issues of accessibility in this project, and although it was not foregrounded in our original project plan we hope to address these questions in more depth in future projects.
} 